\title{
Effect of dietary (n-3) highly unsaturated fatty acids on growth and survival of fat snook (Centropomus parallelus, Pisces: Centropomidae) larvae during first feeding
}

M.E.B. Seiffert ${ }^{1}$,

V.R. Cerqueira ${ }^{1}$ and L.A.S. Madureira ${ }^{2}$
${ }^{1}$ Departamento de Aquicultura, Centro de Ciências Agrárias, and ${ }^{2}$ Central de Análises, Departamento de Q uímica, Centro de Ciências Físicas e Matemáticas, U niversidade Federal de Santa Catarina, Florianópolis, SC, Brasil

\section{Correspondence \\ V.R. Cerqueira \\ Departamento de Aquicultura CCA, UFSC \\ Caixa Postal 476 \\ 88040-970 Florianópolis, SC \\ Brasil \\ Fax: +55-48-331-9653 \\ E-mail: ronzani@mbox1.ufsc.br \\ Research supported by CNPq and FBB.}

Received December 7, 1999 Accepted February 6, 2001

\section{Abstract}

The effect of rotifers, Brachionus rotundiformis (S-type), fed three different diets: A (rotifer fed Nannochloropsis oculata), B (rotifer fed $N$. oculata and baker's yeast, 1:1), and C (rotifer fed $N$. oculata and baker's yeast, $1: 1$, and enriched with Selco ${ }^{\circledR}$ ), was evaluated based on the survival, growth and swim bladder inflation rate of fat snook larvae. Rotifers of treatment A had higher levels $(4.58 \mathrm{mg} / \mathrm{g}$ dry weight) of eicosapentaenoic acid (EPA) than B $(1.81 \mathrm{mg} / \mathrm{g}$ dry weight), and similar levels ( 0.04 and $0.06 \mathrm{mg} / \mathrm{g}$ dry weight, respectively) of docosahexaenoic acid (DHA). Rotifers of treatment $\mathrm{C}$ had the highest levels of EPA $(13.2 \mathrm{mg} / \mathrm{g}$ dry weight) and DHA $(6.08 \mathrm{mg} / \mathrm{g}$ dry weight). Fat snook eggs were obtained by spawning induction with human chorionic gonadotropin. Thirty hours after hatching, 30 larvae/ liter were stocked in black cylindric-conical tanks (36-liter capacity). After 14 days of culture, there were no significant differences among treatments. Mean standard length was $3.13 \mathrm{~mm}$ for treatment A, 3.17 $\mathrm{mm}$ for $\mathrm{B}$, and $3.39 \mathrm{~mm}$ for $\mathrm{C}$. Mean survival rates were very low ( $2.7 \%$ for treatment A, $2.3 \%$ for $\mathrm{B}$, and $1.8 \%$ for C). Swim bladder inflation rates were $34.7 \%$ for treatment $\mathrm{A}, 27.1 \%$ for $\mathrm{B}$, and $11.9 \%$ for $\mathrm{C}$. The lack of differences in growth and survival among treatments showed that the improvement of the dietary value of rotifer may not have been sufficient to solve the problem of larval rearing. Some other factor, probably pertaining to the quality of the larvae, may have negatively influenced survival.

\section{Introduction}

Fat snook (robalo or camorim), Centropomus parallelus Poey, 1860 , is a highly valued sport fish which inhabits the tropical and subtropical western Atlantic (1). Rela-

\author{
Key words \\ - Fish \\ - Larvae \\ - Centropomus \\ parallelus \\ - Feeding \\ - Highly unsaturated fatty \\ acid
}

tively little is known about the biological requirements of this species as a basis for commercial cultivation or restocking programs.

One of the greatest obstacles to the mass production of snook fingerlings is the high 
mortality that occurs in the first two weeks. This mortality may be associated with many factors but, according to previous work (2), priority should be given to the investigation of the influence of light intensity on the feeding habits of larvae and the nutritional quality of live feed.

The rotifer Brachionus spp is widely used in aquaculture because they are an ideal link in the food chain for different stages of fish and shrimp larvae. Its nutritional value is strictly dependent on the nutritional value of its food source, particularly the content of highly unsaturated fatty acids ((n-3) HUFA), like docosahexaenoic acid (DHA, 22:6(n3)) and eicosapentaenoic acid (EPA, 20:5(n$3)$ ). Low dietary HUFA levels can lead to high mortality in fish larviculture (3-5). Koven et al. (6) suggested that such acids function as essential components of biomembranes, and their levels in the tissue phospholipid fraction are associated with larval growth. Rainuzzo et al. (7) emphasized the relevance of DHA to the development of neural tissues such as brain and retina, considering that the larval head constitutes a significant part of the body mass, and that predatory fish larvae rely on vision to capture their food.

Sorgeloos et al. (8) reported a strong correlation between the dietary EPA content and survival, and between DHA and growth of the Asian sea bass larvae. Watanabe (9) concluded that DHA and EPA increased survival and growth of several marine fish larvae. Kanazawa (10) observed that high DHA levels increased the tolerance of red sea bream larvae to various stressful conditions. Barreto and Cavalcanti (11) reviewed live food enrichment techniques with HUFA and its importance to the larvae of marine organisms. All of these findings are relevant to the production of high quality larval fish; however, there are no data concerning Centropomus species or other indigenous Brazilian marine finfish.

In the present study we compared sur- vival, growth, and swim bladder inflation of fat snook larvae fed rotifers reared on different diets, resulting in different fatty acid compositions.

\section{Material and Methods}

\section{O rigin of the larvae}

Wild male and female snook captured by local fishermen in coastal waters near Lagoa da Conceição (Florianópolis, SC, Brazil) were induced to spawn within three days with an intramuscular injection of human chorionic gonadotropin (500 and $1000 \mathrm{IU} /$ $\mathrm{kg}$ body weight, respectively). Gametes were obtained by hand-stripping followed by artificial fertilization. In the incubation process, fiberglass cylindric-conical tanks of 36-liter capacity were placed inside a rectangular tank of 1000-liter capacity, with a stocking density of approximately 2000 eggs/liter. Salinity $(35 \mathrm{~g} / \mathrm{l})$ and temperature $\left(26^{\circ} \mathrm{C}\right)$ were kept constant, and water renewal rate was 2 $1 / \mathrm{min}$.

\section{Live feed culture}

Microalgae Nannochloropsis oculata and rotifers Brachionus rotundiformis (strain obtained from Dr. A. Hagiwara, Nagasaki University, Japan) were cultured in a greenhouse as a semi-continuous system (harvesting $20-30 \%$ daily), using fiberglass tanks of 2500- and 500-liter capacity, respectively. A mixture of agricultural-grade fertilizers was the culture medium used for microalgae (1 liter of freshwater solution, containing $150 \mathrm{~g}$ ammonium sulfate, $25 \mathrm{~g}$ super phosphate, and $7.5 \mathrm{~g}$ urea, for 1000 liters of seawater added to the culture). Temperature range was $22-26^{\circ} \mathrm{C}$. One of the rotifer cultures received $100 \times 10^{3}$ microalga cells per individual/day, while the other received $50 \times 10^{3}$ microalga cells per individual/day and 0.5 $\mu \mathrm{g}$ of baker's yeast per individual/day, as recommended in the literature (12). Rotifer 
enrichment was done with a commercial emulsion (Selco ${ }^{\circledR}$ from INVE Aquaculture $\mathrm{NV}$, Baasrode, Belgium), in 40-liter cylindric-conical tanks at a density of $400 \times 10^{3}$ individuals/liter over $15 \mathrm{~h}$ with $0.2 \mathrm{~g} / \mathrm{l}$ of the product, following manufacturer instructions.

Rotifers were fed three different diets which represented the three treatments, with three replicates: treatment $A$, rotifers fed only microalgae; treatment $\mathrm{B}$, rotifers fed microalgae and baker's yeast $(1: 1)$; treatment $\mathrm{C}$, rotifers fed microalgae and baker's yeast (1:1) enriched with commercial emulsion.

\section{Larviculture}

Approximately $30 \mathrm{~h}$ after hatching, larvae were placed in 9 black cylindric-conical fiberglass tanks (36 liters) at a density of 30 individuals/liter. Each tank was equipped with an airlifting system. Daylight fluorescent lights provided a light intensity of 1000 lux at the water surface, with a photoperiod of $14 \mathrm{~h}$, from 9:00 to 23:00 h. Larvae were fed rotifers from day 3 after hatching onwards, at a density of $10 / \mathrm{ml}$. Microalgae were added to the tanks at $200 \times 10^{3}$ cells $/ \mathrm{ml}$ daily.

Water exchange was approximately $15 \%$ per day. Temperature was monitored at 8:00 $\mathrm{h}$ daily, while salinity, ammonia, $\mathrm{pH}$ and dissolved oxygen were measured every six days, in one tank of each treatment. Temperature $\left(21.3-26.0^{\circ} \mathrm{C}\right)$, non-ionized ammonia (0.07-0.10 mg/1), dissolved oxygen (4.0-5.5 $\mathrm{mg} / \mathrm{l})$, salinity (35 g/l) and $\mathrm{pH}(8.0)$ did not differ significantly among treatments.

On the 14th day after hatching all surviving larvae were counted and 30 larvae per treatment were measured (standard length) using a dissecting microscope equipped with an ocular micrometer. Growth was considered as the difference between final and initial standard length. Individuals with a functional swim bladder in each treatment were counted.

\section{Fatty acid analysis}

Every three days, approximately one million rotifers were filtered from the different cultures through $65-\mu \mathrm{m}$ mesh screens, and then frozen at $-20^{\circ} \mathrm{C}$. After lyophilization of the samples and addition of internal standards (nonadecanol and colestane dissolved in chloroform) the fatty acids were extracted with 1:3 dichloromethane-methanol $(3 x)$ by ultrasound, followed by centrifugation.

The total combined extracts were evaporated and the fatty acids methylated under $\mathrm{N}_{2}$ using anhydrous 5\% methanolic $\mathrm{HCl}$ in toluene at $50^{\circ} \mathrm{C}$ for $12 \mathrm{~h}$ (13). After esterification, $1 \mathrm{ml}$ aqueous $\mathrm{NaCl}(5 \%)$ was added and the methylated products were extracted into dichloromethane. The samples were then analyzed using a Shimadzu Gas Chromatographer (GC) model 14A equipped with a split/splitless injector and flame ionization detector, using a $25 \mathrm{~m} \times 0.25 \mathrm{~mm}$ ID CBP1 column (film thickness $0.25 \mu \mathrm{m}$ ). The temperature program was $40-300^{\circ} \mathrm{C}$ at $10^{\circ} \mathrm{C} /$ min. Nitrogen was used as a carrier gas. GCmass spectrometry (MS) analyses (EI mode, $70 \mathrm{eV}$ ) were carried out on a QP2000A Shimadzu GC-MS. Conditions for GC-MS analyses were as for GC except that helium was used as the carrier gas (14).

There were no chemical reactions to identify the position of the first unsaturation in the fatty acids (series (n-3), (n-6), etc.). The 20:5(n-3) and 22:6(n-3) fatty acids were compared to a standard product (Super Selco ${ }^{\circledR}$ from INVE Aquaculture NV).

\section{Statistical analysis}

Survival and swim bladder inflation data were compared among treatments by the nonparametric chi-square test. Final standard length $(\mathrm{N}=30$ for each treatment) was compared by one-way analysis of variance (ANOVA). A significance level of 5\% was used for both tests (15). 


\section{Results and Discussion}

Rotifers fed microalgae showed a higher content of most fatty acids (Table 1), especially 16:0, 16:1, and 20:5(n-3) compared to rotifers fed microalgae and baker's yeast. Replacement of $50 \%$ of the microalgae with yeast yielded a reduction in total fatty acids corresponding to $162 \%$ for saturated fatty acids, $61 \%$ for monounsaturated fatty acids, and $117 \%$ for polyunsaturated fatty acids. However, there was no decrease in the amount of some fatty acids (18:3(n-3) and 22:6(n-3), for example). In the oil-enriched rotifers there was an increase in the level of

Table 1. Fatty acid content ( $\mathrm{mg} / \mathrm{g}$ dry weight) of rotifers fed on different diets and used as feed for fat snook larvae.

\begin{tabular}{|c|c|c|c|}
\hline \multirow[t]{2}{*}{ Fatty acids } & \multicolumn{3}{|c|}{ Diets } \\
\hline & Microalgae & $\begin{array}{c}\text { Microalgae } \\
\text { + yeast }\end{array}$ & $\begin{array}{r}\text { Microalgae } \\
+ \text { yeast + oil }\end{array}$ \\
\hline 14:0 & 1.36 & 0.53 & 3.97 \\
\hline 15:0i & 0.03 & 0.06 & 0.15 \\
\hline 15:0 & 0.18 & 0.17 & 0.36 \\
\hline 16:1 & 5.41 & 1.99 & 10.33 \\
\hline 16:0 & 7.27 & 2.45 & 11.39 \\
\hline 17:0i & 0.07 & 0.04 & 0.06 \\
\hline $17: 0 a$ & 0.01 & 0.06 & 0.28 \\
\hline $17: 0$ & 0.09 & 0.03 & 0.17 \\
\hline $18: 3(n-3)$ & 0.04 & 0.07 & 1.57 \\
\hline $18: 2(n-6)$ & 1.27 & 0.77 & 3.18 \\
\hline 18:1 & 1.99 & 2.61 & 9.35 \\
\hline 18:0 & 1.11 & 0.65 & 2.52 \\
\hline 20:5(n-3) - EPA & 4.58 & 1.81 & 13.20 \\
\hline $20: 2(n-6)$ & 0.83 & 0.40 & 2.23 \\
\hline $21: 0$ & 0.17 & 0.01 & 0.41 \\
\hline $22: 6(n-3)-D H A$ & 0.04 & 0.06 & 6.08 \\
\hline $22: 5(n-3)$ & 1.55 & 0.61 & 2.39 \\
\hline $22: 0$ & 0.08 & 0.05 & 0.09 \\
\hline $24: 0$ & 0.29 & 0.02 & 0.13 \\
\hline Saturated & 10.68 & 4.07 & 19.54 \\
\hline Monounsaturated & 7.40 & 4.60 & 19.68 \\
\hline Polyunsaturated & 6.75 & 3.11 & 26.27 \\
\hline (n-3) HUFA & 6.21 & 2.55 & 23.24 \\
\hline DHA/EPA & 0.008 & 0.03 & 0.46 \\
\hline Total & 26.38 & 12.39 & 67.87 \\
\hline
\end{tabular}

i: iso, a: anteiso; DHA: docosahexaenoic acid; EPA: eicosapentaenoic acid; HUFA: highly unsaturated fatty acids. almost all fatty acids. The most notable were 20:5(n-3), 22:6(n-3), 22:5(n-3), 16:1, 16:0, and 14:0. The enrichment process increased the total saturated fatty acid content by $380 \%$, the monounsaturated fatty acid content by $328 \%$, and the polyunsaturated fatty acid content by $744 \%$ in relation to the rotifers fed microalgae and baker's yeast.

The levels of HUFA tested in treatment $\mathrm{C}$ of the present study were within the range recommended in the literature for other marine species. Lavens and Sorgeloos (16) stated that rotifers grown on a formulated feed had an excellent HUFA composition, containing 5.4, 4.4 and $15.6 \mathrm{mg} / \mathrm{g}$ dry weight of EPA, DHA and (n-3) HUFA, respectively. Rodríguez et al. (17) found that the minimum requirement for larval gilthead sea bream ( 0 17 days) fed rotifers was $6 \mathrm{mg} / \mathrm{g}$ of EPA, 8 $\mathrm{mg} / \mathrm{g}$ of DHA and $15 \mathrm{mg} / \mathrm{g}$ dry weight of (n3) HUFA.

There was no significant effect of treatment on survival $\left(\chi^{2}=5.8<\chi^{2}{ }_{\mathrm{c}}=7.8\right)$ or swim bladder inflation $\left(\chi^{2}=3.7<\chi_{\mathrm{c}}^{2}=7.8\right)$. Survival rates were particularly low, the highest being $2.7 \%$ in treatment A. Swim bladder inflation rates were $11.9-34.7 \%$ (Table 2 ).

One important observation about survival, which was not quantified, is that most losses occurred from 6 to 9 days after hatching for all treatments. By this time, with the yolk sac exhausted, most larvae had not fed, were motionless, apparently weak and starving in comparison to a few healthy individuals.

About $30 \mathrm{~h}$ after hatching larvae presented a mean standard length of $2.45 \pm$ $0.038 \mathrm{~mm}(\mathrm{~N}=30)$. After 14 days of rearing, there were no significant differences among treatments in final length (ANOVA: $\mathrm{F}=$ 1.35 , d.f. $=2, \mathrm{P}=0.263)$ or growth (Table 2$)$.

Despite the differences in the composition of essential fatty acids in each rotifer treatment, there was no influence on the larviculture performance of fat snook. Similarly, Tamaru et al. (18), by replacing $50 \%$ of the microalgae with baker's yeast in the rotifer diet, obtained small differences in 
survival and growth of milkfish and striped mullet larvae. While Koven et al. (6) observed that enriching rotifers with different oils enhanced the growth rate of gilthead sea bream larvae, but found no influence on survival and swim bladder inflation. Mourente et al. (19) and Rodríguez et al. (17), working with the same species, also observed a positive effect of (n-3) HUFA only on the growth of first-feeding larvae (0-17 days). Dhert et al. (20), rearing Asian sea bass larvae (0-21 days), obtained no improvement in growth or survival of larvae fed (n-3) HUFA-enriched food; however, an increase in larval resistance to the salinity stress test was observed.

Some authors have concluded that DHA is superior to EPA as an essential fatty acid for larval fish. Watanabe (9) studied the larviculture of five marine fish (red sea bream, yellowtail, striped knifejaw, Japanese flounder, and turbot) and found that DHA was necessary in greater quantities than EPA, and that its presence in adequate quantities increased survival and growth. Similarly, Rodríguez et al. (21), rearing gilthead sea bream larvae, observed that the best growth rate was achieved with a DHA:EPA ratio of about 1:3. Ibeas et al. (22) obtained the best growth of gilthead sea bream larvae with a ratio of 2, while in the juvenile stage the best ratio was found to be 0.5 . The highest DHA:EPA ratio found in the present study was 0.46 (treatment $C$ with oil-enriched rotifers).

Some investigators have proposed that the presence of (n-3) HUFA may not be important for young (newly hatched) larvae. Kraul (23) reported that the first stage survival (0-9 days) of mahimahi larvae was not affected by the content of fatty acids in the feed, and suggested that this is probably due to high levels of endogenous EPA and DHA stored in the larval yolk sac. Watanabe (9) reported that DHA is high in the eggs of marine fish and rapidly decreases during the first ten days after hatching. Mourente et al.
(19) suggested that the presence of DHA in the diet of larval gilthead sea bream may not be necessary, because they could retain DHA from the yolk. Thus, if the first-feeding fat snook does not depend on the (n-3) HUFA content of the exogenous feed, as observed with other species, rotifer enrichment at this stage may not be necessary, thus simplifying and lowering the cost of larviculture.

The (n-3) HUFA requirements of marine larval fish are highly variable. Such differences could be explained by species-specific nutritional requirements, culture period, or quality of larvae. The latter can be influenced by both the nutritional conditions during gonad formation (24) and the process used for spawning induction of broodstock (25). Tamaru et al. (26) also correlated differences in growth and survival of striped mullet larvae to the quality of broodstock nutrition. Abi-Ayad et al. (27) found a correlation with DHA and EPA levels in the broodstock diet, and stress resistance and survival of perch larvae.

The low survival rates (under $2.7 \%$ ) obtained in the present study can also be correlated with factors other than the nutritional value of the rotifers. For example, the use of wild spawners, probably not well acclimated, and artificial reproduction methods could have resulted in low quality larvae. Wallace et al. (28) observed in common snook, Centropomus undecimalis, that adult fish appeared to be unusually traumatized by the stress of capture and translocation, and that $48 \mathrm{~h}$ after capture ovaries began to degener-

Table 2. Survival, swim bladder inflation, final standard length and growth of fat snook larvae reared for 14 days on rotifers fed different diets.

\begin{tabular}{lcccc}
\hline Treatment & $\begin{array}{c}\text { Survival } \\
(\%)\end{array}$ & $\begin{array}{c}\text { Swim bladder } \\
\text { inflation }(\%)\end{array}$ & $\begin{array}{c}\text { Final length } \\
(\mathrm{mm})\end{array}$ & $\begin{array}{c}\text { Growth } \\
(\mathrm{mm})\end{array}$ \\
\hline Microalgae & $2.7 \pm 1.4$ & $34.7 \pm 9.7$ & $3.13 \pm 0.08$ & $0.68 \pm 0.08$ \\
Microalgae + yeast & $2.3 \pm 1.4$ & $27.1 \pm 10.4$ & $3.17 \pm 0.05$ & $0.72 \pm 0.05$ \\
Microalgae + yeast + oil & $1.8 \pm 0.9$ & $11.9 \pm 6.3$ & $3.39 \pm 0.19$ & $0.95 \pm 0.19$
\end{tabular}

Data are reported as means \pm SEM of three replicates. 
ate. The swim bladder inflation rates observed (lower than $34.7 \%$ ) are indicative of a state of weakness. Brügger (29), working with fat snook larvae of the same age under conditions very similar to those of the present study, obtained highly variable rates ( 37 to $100 \%$ ) of swim bladder inflation. It was observed in other species that lack of an inflated swim bladder affects mainly larval growth, but affects survival only later during weaning (30). With snook, inflation occurs very early, around 5-7 days after hatching, and larvae are able to feed even without a normally inflated swim bladder $(2,29)$. This phenomenon has already been described for several marine species $(30,31)$. Concerning larval mortality, other studies $(2,29$, and Cerqueira VR, unpublished results) achieved survival rates up to $20 \%$ and occasionally higher with fat snook larvae fed non-enriched rotifers (low HUFA levels).

Another sign of low quality larvae was a period between 6 and 9 days after hatching of high mortality rates coincident with yolk sac depletion. Larvae might have had difficulty capturing prey if there was some kind of weakness or malformation (induced, for example, by a biochemical deficiency in the eggs), and might have starved to death. The transition from endogenous to exogenous feeding is normally a vulnerable period for many species, when endogenous factors may acquire some importance (32). Rodríguez et al. (17) observed a notable mortality of gilthead sea bream larvae during the first 23 days of external feeding. Brügger (29) also noticed the same problem in some experiments with fat snook.

Finally, the improvement of the dietary value of rotifers was not sufficient to solve the problem of larval rearing. The high mortality obtained just after yolk absorption was probably due to some other factor. In order to improve survival of first-feeding fat snook larvae, factors other than the dietary HUFA level should also be considered in the future.

\section{Acknowledgments}

We thank Drs. N. Yamanaka, E. Zaniboni Filho, L. Alvarez-Lajonchere and D. Fracalossi for their comments, and Mr. Shelby Banner for revising the English manuscript.

\section{References}

1. Rivas LR (1986). Systematic review of the perciform fishes of the genus Centropomus. Copeia, 3: 579-611.

2. Cerqueira VR, MacChiavello JAG \& Brügger AM (1995). Produção de alevinos de robalo, Centropomus parallelus Poey, 1860, através de lanvicultura intensiva em laboratório. In: Castagnolli N (Editor), Anais do Encontro Nacional de Aqüicultura, VII SIMBRAq, II ENBRAPOA. Peruíbe, SP, Brazil. Publicação ACIESP, 191197.

3. Scott AP \& Middleton C (1979). Unicellular algae as a food for turbot (Scophthalmus maximus L.) larvae - The importance of dietary long-chain polyunsaturated fatty acids. Aquaculture, 18: 227-240.

4. Watanabe T, Kitajima C \& Fujita S (1983). Nutritional values of live organisms used in J apan for mass propagation of fish. Aquaculture, 34: 115-143.
5. Caric M, Sanko-Njire J \& Skaramuca B (1993). Dietary effects of different feeds on the biochemical composition of the rotifer (Brachionus plicatilis Müller). Aquaculture, 110: 141-150.

6. Koven WM, Tandler A, Kissil GW, Skland D, Friezlander O \& Harel M (1990). The effect of dietary (n-3) polyunsaturated fatty acids on growth, survival and swim bladder development in Sparus aurata larvae. Aquaculture, 91: 131-141.

7. Rainuzzo J R, Reitan KI \& Olsen Y (1997). The significance of lipids at early stages of marine fish: a review. Aquaculture, 155: 103-115.

8. Sorgeloos P, Léger PH \& Lavens P (1988). Improved larval rearing of European and Asian seabass, seabream, mahimahi, siganid and milkfish using enrichment diets for Brachionus and Artemia. World Aquaculture, 19: 78-79.
9. Watanabe T (1993). Importance of docosahexaenoic acid in marine larval fish. J ournal of the World Aquaculture Society, 24: 153-161.

10. Kanazawa A (1997). Effects of docosahexaenoic acid and phopholipids on stress tolerance of fish. Aquaculture, 155: 129134.

11. Barreto O \& Cavalcanti D (1997). Enriquecimento de alimentos vivos para alimentação de larvas de organismos marinhos: uma breve revisão. Boletim do Instituto de Pesca, 24: 139-159.

12. Fulks W \& Main K (1991). Rotifer (Brachionus plicatilis) production systems. In: Fulks W \& Main K (Editors), Rotifer and Microalgae Culture Systems. Proceedings of a US-Asia Workshop. Oceanic Institute, Honolulu, 23-46.

13. Christie WW (1982). Lipid Analysis. Pergamon Press, New York. 
14. Madureira LAS, Conte MH \& Eglinton G (1995). Early diagenesis of lipid biomarker compounds in North Atlantic sediments. Paleoceanography, 10: 627-642.

15. Sokal RR \& Rohlf FJ (1981). Biometry. The Principles and Practice of Statistics in Biological Research. 2nd edn. WH Freeman, New York.

16. Lavens P \& Sorgeloos P (1996). Manual on the Production and Use of Live Food for Aquaculture. FAO Fisheries Technical Paper No. 361. FAO, Rome.

17. Rodríguez $C$, Pérez J A, Badía $P$, Izquierdo MS, Fernández-Palacios $H \&$ Lorenzo Hernández A (1998). The n-3 highly unsaturated fatty acid requirements of gilthead seabream (Sparus aurata L.) larvae when using an appropriate DHA/EPA ratio in the diet. Aquaculture, 169: 9-23.

18. Tamaru CS, Lee C \& Ako H (1991). Improving the larval rearing of striped mullet (Mugil cephalus) by manipulating quantity and quality of the rotifer, Brachionus plicatilis. In: Fulks W \& Main K (Editors), Rotifer and Microalgae Culture Systems. Proceedings of a US-Asia Workshop. Oceanic Institute, Honolulu, 89-103.

19. Mourente G, Rodriguez A, Tocher DR \& Sargent J R (1993). Effects of dietary do-

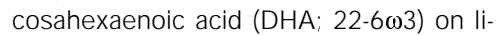
pid and fatty acid compositions and growth in gilthead sea bream (Sparus aurata $L$.) larvae during first feeding. Aquaculture, 112: 79-98.
20. Dhert $P$, Lavens $P$, Duray $M \&$ Sorgeloos $P$ (1990). Improved larval survival at metamorphosis of Asian seabass (Lates calcarifer) using (n-3)-HUFA enriched live food. Aquaculture, 90: 63-74.

21. Rodríguez C, Pérez J A, Días M, Izquierdo MS, Fernández-Palacios $\mathrm{H}$ \& Lorenzo A (1997). Influence of EPA/DHA ratio in rotifers on gilthead seabream (Sparus aurata) larval development. Aquaculture, 150: 7789.

22. Ibeas C, Cejas J R, Flores R, Badía P, Gómez T \& Lorenzo Hernández A (1997). Influence of eicosapentaenoic to docosahexaenoic acid ratio (EPA/DHA) of dietary lipids on growth and fatty acid composition of gilthead seabream (Sparus aurata) juveniles. Aquaculture, 150: 91-102.

23. Kraul S (1993). Larviculture of the mahimahi Coryphaena hippurus in Hawaii, USA. J ournal of the World Aquaculture Society, 24: 410-421.

24. Lavens $P \&$ Sorgeloos $P$ (1991). Variation in egg and lanval quality in various fish and crustacean species. In: Lavens $P$, Sorgeloos $\mathrm{P}$, J aspers $\mathrm{E} \&$ Ollevier $\mathrm{F}$ (Editors), Larvi'91 - Fish and Crustacean Larviculture Symposium. Vol. 15. European Aquaculture Society, Special Publication, 221-222.

25. Lam TJ (1991). Hormones and egg/lanval quality in fish. In: Lavens $\mathrm{P}$, Sorgeloos $\mathrm{P}$, J aspers E \& Ollevier F (Editors), Lanvi'91 Fish and Crustacean Larviculture Symposium. Vol. 15. European Aquaculture So- ciety, Special Publication, 197.

26. Tamaru CS, Murashige R \& Lee C (1994). The paradox of using background phytoplankton during the larval culture of striped mullet, Mugil cephalus L. Aquaculture, 119: 167-174.

27. Abi-Ayad S-M E-A, M elard C \& Kestemont $P$ (1997). Effects of (n-3) fatty acids in Eurasian perch broodstock diet on egg fatty acid composition and larvae stress resistance. Aquaculture International, 5: 161-168.

28. Wallace RA, Boyle SM, Grier HJ , Selman K \& Petrino TR (1993). Preliminary observations on oocyte maturation and other aspects of reproductive biology in captive female snook, Centropomus undecimalis. Aquaculture, 116: 257-273.

29. Brügger AM (1995). Efeito da intensidade luminosa na sobrevivência e na insuflação da bexiga gasosa de larvas de robalo Centropomus parallelus (Poey, 1860). Master's thesis, Universidade Federal de Santa Catarina, Florianópolis, SC, Brazil.

30. Chatain B (1997). Development and achievements of marine fish-rearing technology in France over the last 15 years. Hydrobiologia, 358: 7-11.

31. Planas M \& Cunhal (1999). Lanviculture of marine fish: problems and perspectives. Aquaculture, 177: 171-190.

32. Kamler E (1992). Mixed feeding period. In: Early Life History of Fish. Chapman \& Hall, London, 176-181. 